\title{
Multi-objective optimisation of a seasonal solar thermal energy storage system combined with an earth - Air heat exchanger for net zero energy building
}

\author{
M.H. Benzaama ${ }^{a, *}$, S. Menhoudj ${ }^{\text {b }}$, M.C. Lekhal ${ }^{\text {c, }}$, A. Mokhtari ${ }^{\text {b }}$, S. Attia ${ }^{\text {d }}$ \\ ${ }^{a}$ COMUE Normandie Université-Laboratoire de Recherche ESITC-ESITC Caen, 1 Rue Pierre et Marie Curie, 14610 Epron, France \\ ${ }^{\mathrm{b}}$ LMST Laboratoire, Université des Sciences et de la Technologie, 31000 Oran, Algeria \\ ${ }^{\mathrm{c}}$ MSME Laboratoire, UMR-8208 CNRS, Université Gustave Eiffel, 77420 Marne-la-Vallée, France \\ ${ }^{\mathrm{d}}$ Sustainable Building Design Lab, Dept. UEE, Applied Sciences, Université de Liege, Belgium
}

\section{A R T I C L E I N F O}

\section{Keywords:}

Underground Tank (UNT)

Earth-Air Heat Exchanger (EAHE)

Solar thermal collector

Geo-solar system

Net Zero Energy Buildings (NZEBs)

\begin{abstract}
A B S T R A C T
Net Zero Energy Building (NZEB) is a high performance building concept that integrates passive design and renewable energy systems. The aim of this paper is to analyze the performance of multi-integrated renewable energy systems for nearly zero energy buildings in the Mediterranean context. Taking into account the particular technical characteristics of net-zero energy buildings, this study focuses on three different systems: 1) an Earth Air Heat Exchanger (EAHE), 2) an Underground Tank (UNT) and 3) a Solar Thermal Collector. The first step of the methodology was to study the energy efficiency of the combination between EAHE and UNT for heating needs. An experimental facility equipped with monitoring sensors was constructed. For the second step, we propose a numerical study of the energy performance of the UNT coupled with a solar thermal collector and combined with an EAHE in order to improve the coverage rate of heating needs. The results show that the combination of the three systems satisfied all the needs with a rate of $131 \%$ for the climatic conditions of Oran, Algeria. On the other hand, the EAHE and UNT systems operating separately covered $49.3 \%$ and $41.7 \%$, respectively. Combining three systems simultaneously saves $37.9 €$ (or $232.8 \mathrm{kWh}$ of energy needs) and reduces by 21.1 tons of $\mathrm{CO} 2$ emissions during the heating period.
\end{abstract}

\section{Introduction}

Reducing dependence on fossil fuels remains a vital priority in the civil engineering sector. Low-temperature heating is one of the concrete solutions that can alleviate this dependency and reduce building energy needs. NZEBs are considered as low energy demand buildings, 30\% of which are covered by renewable energy (Pideritet al., 2019). Therefore, this research aims to apply three different renewable energy systems to cover the heating needs of buildings in the Mediterranean climate of Algeria. In this state of the art, two techniques are presented: EAHEs and Seasonal Solar Thermal Energy Storage (SSTES).

The EAHE is a geothermal system used to preheat residential spaces in winter. For the Central European climate, Popiel et al. (2001) show that soil temperature is fairly stable at a depth of about $2 \mathrm{~m}$ and varies from 4 to $10{ }^{\circ} \mathrm{C}$ depending on the soil thermal properties, soil cover and season. Concerning the Western European climate, Chel et al. (2015) analysed the energy performance of a near-zero energy house equipped with an Air-Air Heat Exchanger (AAHE), an Earth-Water Heat Exchanger (EWHE) and a Water-Air Heat Exchanger (WAHE), for the Belgian climate conditions. The performance of the house and the systems mentioned below are evaluated using a thermal model developed under TRNSYS software. The results show that the AAHE and the EWHE have impact of $66 \%$ and $7 \%$ respectively on reduction of the annual heating consumption of the house. Nearby, in France, the energy and environmental performance of a passive house equipped with a ventilation system powered by an EAHE was evaluated Thiers and Peuportier (2008). The results show a reduction in energy consumption and discomfort in summer for the passive house compared to a standard house. For the Eastern European climate, Amanowicz and Wojtkowiak (2018) numerically studied multi-pipe EAHEs for the Polish climate conditions. The results show that the air flow generated by each pipe is different. The authors mentioned that the results could be useful for a good dimensioning of EAHEs in order to reduce energy consumption and

\footnotetext{
* Corresponding authors.

E-mail addresses: mohammed-hichem.benzaama@esitc-caen.fr (M.H. Benzaama), mohammed-cherif.lekhal@u-pem.fr (M.C. Lekhal).
} 


\begin{tabular}{|c|c|c|c|}
\hline \multicolumn{2}{|c|}{ Nomenclature } & $\boldsymbol{U A}$ & overall loss coefficient (W/k) \\
\hline \multicolumn{2}{|c|}{ Letter symbols } & $A_{\text {pipe }}$ & inside surface of the pipe $\left(\mathrm{m}^{2}\right)$ \\
\hline$T$ & temperature $\left({ }^{\circ} \mathrm{C}\right)$ & $\Delta \boldsymbol{T}_{l n}$ & logarithmic temperature $\left({ }^{\circ} \mathrm{C}\right)$ \\
\hline$\rho$ & density $\left(\mathrm{kg} / \mathrm{m}^{3}\right)$ & $\Delta h$ & separation between centers of segments \\
\hline$C_{p}$ & heat capacity of water $(\mathrm{J} / \mathrm{kg} \mathrm{K})$ & Qc & energy benefits provided (kWh) \\
\hline$\dot{m}$ & mass flow rate $(\mathrm{kg} / \mathrm{s})$ & \multirow{2}{*}{\multicolumn{2}{|c|}{ Subscripts }} \\
\hline$\delta_{s}$ & soil thermal diffusivity $\left(\mathrm{m}^{2} / \mathrm{s}\right)$ & & \\
\hline$A_{s}$ & $\begin{array}{l}\text { amplitude of soil surface temperature throughout the year } \\
\text { (K) }\end{array}$ & $\begin{array}{l}s \\
w\end{array}$ & $\begin{array}{l}\text { soil } \\
\text { water }\end{array}$ \\
\hline$T_{m}$ & mean surface temperature $\left({ }^{\circ} \mathrm{C}\right)$ & in & inlet \\
\hline$T_{\text {ent }}$ & Environmental temperature $\left({ }^{\circ} \mathrm{C}\right)$ & out & outlet \\
\hline$t$ & time $(\mathrm{h})$ & $\mathrm{m}$ & mean \\
\hline$t_{0}$ & time of year with minimum soil surface temperature (hour) & $\ln$ & logarithm \\
\hline$Z$ & soil depth (m) & ent & environmental \\
\hline
\end{tabular}

operational costs of low-energy buildings. For the southern European climate, Chiesa et al. (2014) experimentally studied the energy efficiency of an EAHE located in central Italy. The appropriate depth was between 2 and $3 \mathrm{~m}$ and the pipe length was not significantly affecting the thermal performance. The results showed that the EAHE system can significantly reduce the cooling energy demand of the building in the mild Mediterranean climate.

For the Mediterranean climate, Rosa et al. (2020) developed a numerical study to evaluate the impact of three parameters (pipe spacing, pipe diameter and air flow velocity) on the overall thermal performance of an EAHE for residential buildings located in Coimbra, Portugal. The results show that the EAHE system operating in heating mode cannot provide thermal comfort because the outlet air temperatures obtained are very low. On the one hand, Lekhal et al. (2019) studied the thermal performance of a residential building integrating an EAHE in the Mediterranean climate of Oran, Algeria. They observed that the air temperature at the outlet of the EAHE varied from 15.2 to $19{ }^{\circ} \mathrm{C}$, while the temperature of the outdoor air ranged from 9 to $23.5{ }^{\circ} \mathrm{C}$. Therefore, a maximum gain of $7.3{ }^{\circ} \mathrm{C}$ was provided by the EAHE. The heating needs are reduced by $46 \%$ using the EAHE and the thermal comfort hour ratio was estimated at $31 \%$ during the winter. Furthermore, Ozgener and Ozgener (2010) showed that the EAHE was able to provide $46 \%$ of the design heating load for, Izmir climate conditions, in Turkey.

The combination of a low-temperature heating system and seasonal storage was studied by several researchers and for different climatic regions. Nordell and Hellström (2000) conducted a theoretical study on solar-heated premises with seasonal storage in Anneberg, Sweden, to meet $60 \%$ of heating needs for a heat demand of 1080 MWh. In France weather conditions, Berdal et al. (2006) conducted an experimental study of a ground-coupled heat pump used in a $180 \mathrm{~m}^{2}$ private residence combined with thermal solar collectors. They have shown that the energy injected into the ground represents $34 \%$ of the heat extracted, and the heat pumps' coefficient of performance (COP) in heating mode had an average value of 3.75. In Turkey, Hasan et al. (2020) developed a model for a wheat drying system with a heat pump and UNT charged by solar energy. The results indicate that the thermos-physical characteristics of the geological structure around the UNT have a significant impact on the energy performance of the system. Thus, it is recommended that a suitable region should be selected for installing such a system. Banjac (2015) showed that for Belgrade weather conditions, the size of the tanks has a significant effect on the water temperature and that temperature amplitude decreases with tank volume increment. They confirmed that smaller size solar collectors could be used to ensure the sustainability of the system. Furthermore, Huang et al. (2020) showed that the heat storage capacity of the system can be effectively improved by insulating only the upper half of the tank at 3 or $4 \mathrm{~m}$ from the tank surface for Taiyuan weather conditions in China.
There are three promising studies in the Mediterranean region; which are being developed in Naples and Palermo, in the South of Italy (Rosato et al. 2019, Panno et al. 2019), and in the South of Spain (Lizana et al., 2017). However, in these studies, the underground seasonal storage is achieved by using boreholes and not with a hot tank. Research activity has been carried out on three issues related to net-zero energy building (NZEB) concpet in the Mediterranean climates:

- The contribution of a hot tank seasonal storage charged by solar energy;

- Renewable energy combination;

- The possibility to obtain a NZEB using only renewable energy.

In this context, Martin-Escudero et al. 2019 proposed a novel system composed of a photovoltaic double skin façade (PV-DSF) coupled to an air source heat pump system (ASHP). The main goal of this system is to provide heating and domestic hot water (DHW) using renewable energy. The results showed that, the PV-DSF panels can supply approximately $70 \%$ of the electricity consumed by the ASHP system and the fans of the PV-DSF. Furthermore, Asier Sanz et al. 2018 have developed a study on the analysis of dual use of solar resource by means of hybrid collectors and their smart combination with heat pumps through predictive control strategies towards entire-lifetime feasible solutions. The financial result showed that the Solar hybrid PVT based solution extra investment is easily returned during its lifetime,

The design and construction materials of the building are among the most important criteria for having a net-zero energy building (NZEB). For this purpose, Stazi, et al. 2020 have investigated how different materials and thermal masses impact on the performance of ventilated facades with narrow cavities, by measuring the variation in terms of heat flows and ventilation efficiency. It was concluded that the adoption of a massive material represented the optimal solution on annual basis, considering both the thermo-physical performance and the natural ventilation potential. An experimental and numerical study was carried out by Ulpiani et al. (2017) in order to compare the energy performance of a NZEB mock-up plus sunspace coupled system according to different setup configurations. The results showed that the addition of an extra glass layer was responsible of a quite constant reduction of $1 \mathrm{kWh} /$ day.

For northern Algeria which enjoys a Mediterranean climate, no study on the contribution of a hot tank seasonal storage charged by solar energy has been conducted. However, there are two studies on the use of an UNT for the cooling period for Oran city, in Algeria. The first study investigated the energy performance of an UNT coupled to a cooling floor. Benzaama et al. (2019) showed in this study that a tank volume of $4 \mathrm{~m}^{3}$ is not enough to reduce the cooling need of an experimental cell of $48 \mathrm{~m}^{3}$. This system ensures a gain of $45.43 \%$. For this purpose, in the second study Benzaama et al. (2018) have combined an UNT and EAHE 
to reduce the cooling need. The results showed that this system ensures a gain of $59.12 \%$ for the cooling period. However, no study has been done for Mediterranean climates on the combination between the buried tank and EAHE for heating period.

Despite the presence of several studies on solar-based heating systems there are practically no studies combining three renewable energy systems namely; a UNT charged by solar energy and EAHE. The coupling of solar heating systems with thermal storage for renewable-based heating systems is a promising technology in the Mediterranean climate.

There is a potential of solar energy in the Mediterranean region and in particular North Algeria, where approximately $1700 \mathrm{kWh} / \mathrm{m}^{2} /$ year of received average solar energy and $4.66 \mathrm{kWh} / \mathrm{m}^{2}$ of solar daily energy density Bouraiou et al. (2020). To harness this energy, we present a combination of EAHE and UNT charged by solar energy, to create a thermal load for the tank water. Numerical simulations are carried out by coupling the buried tank to a solar thermal collector. Naranjo et al. (2019) showed that the seasonal solar storage system needs a control strategy to improve energy performance. For this purpose, a control strategy is also proposed, in this paper. The control strategy suggests to operate the pump circulation intermittently to favor the capture of solar radiation during the day. A sensitivity study has been developed by varying different parameters, such as area solar thermal collector and storage volume.

The research questions corresponding to the objectives are:

- What is the thermal performance of the combined geothermal system (EAHE and UNT)?

- What are the benefits of the design optimization by integrating the solar thermal collector with combined geothermal system?

- What is the best configuration for the solar collector surface and storage volume of the UNT?

- What are the economic benefits and energy savings of the system?

- Can $\mathrm{CO} 2$ emissions be reduced when compared to a conventional system?

- What are the implications of multi-integrated renewable energy systems (solar and geothermal systems) on practice?

Thus the present paper provides a valuable contribution to the new body of knowledge from an international perspective. The study is useful for cities that are the same climate conditions, such as Oran city, as shown in Fig. 1.

The paper is organized as follows: Section 2 describes the overall principle of the proposed system. Then, the study methodology is presented in Section 3. The Sections 4 and 5 focus on the analysis and discussion of results, followed by recommendations and conclusions.

\section{System description and operating principle}

The description and operating principle of the Geo-solar system is illustrated in Fig. 1. It combines an EAHE with an UNT recharged by a solar thermal collector in order to optimize its heating performance. The system operates in this way: solar radiation is captured by the solar collector through which heat is transferred to the water stored in the UNT by thermally charging it. The hot water is then fed into the heating floor system, which in turn heats the inside air of the building. In the meantime, outdoor air is aspirated and circulated through the EAHE. The air inside the pipe is heated by the ground and then blown in the building. In this case, the indoor air of the building is simultaneously heated by the floor heating and the air blown by the EAHE.

\section{Methodology}

The conceptual study plan for this research includes three important parts, as detailed in Fig. 2. The first part is to experimentally evaluate the thermal behavior and energy contribution of the geothermal system composed of an EAHE combined with an UNT. The experimental data was also used to calibrate and validate the model.

The second part, focuses on optimizing the combined geothermal system configuration in order to fit real NZEB. The optimization was numerically performed using the TRNSYS software by coupling a solar thermal collector to a UNT.

Three renewable energy systems were tested: an UNT loaded by a solar thermal collector and an EAHE. In addition, a sensitivity analysis was conducted in order to identify the most relevant parameters on the system energy performance. Several simulations are performed to investigate a multi-objective optimization for a good sizing system. The last step of this study is to assess the energy consumption of the proposed system, the cost of energy consumption, and the amount of $\mathrm{CO} 2$ emissions. Our conceptual study framework is detailed in the following subsections.

\subsection{Experimental study}

The experimental study is carried out using a test cell equipped with renewable energy systems, mainly solar and geothermal. The cell is located at the Institute of Civil and Mechanical Engineering of the University of Sciences and Technology of Oran, Algeria, where the

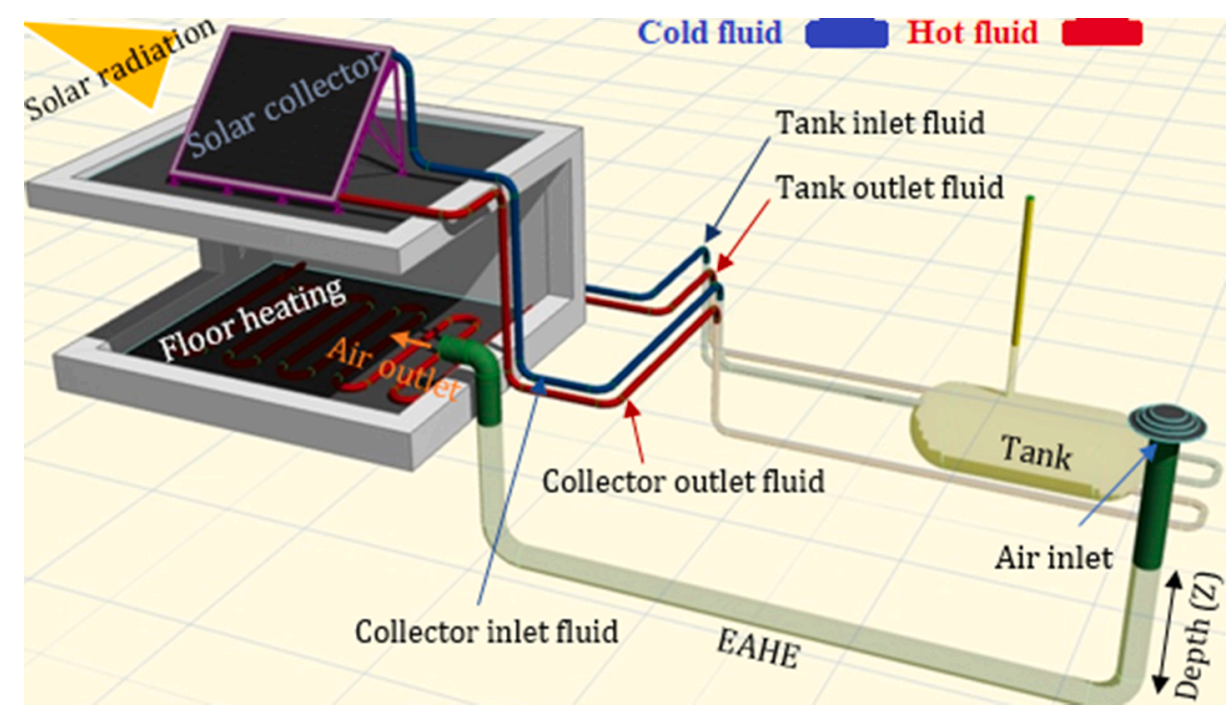

Fig. 1. Geo-solar system (EAHE, UNT and solar collector) coupled to the test cell for heating. 


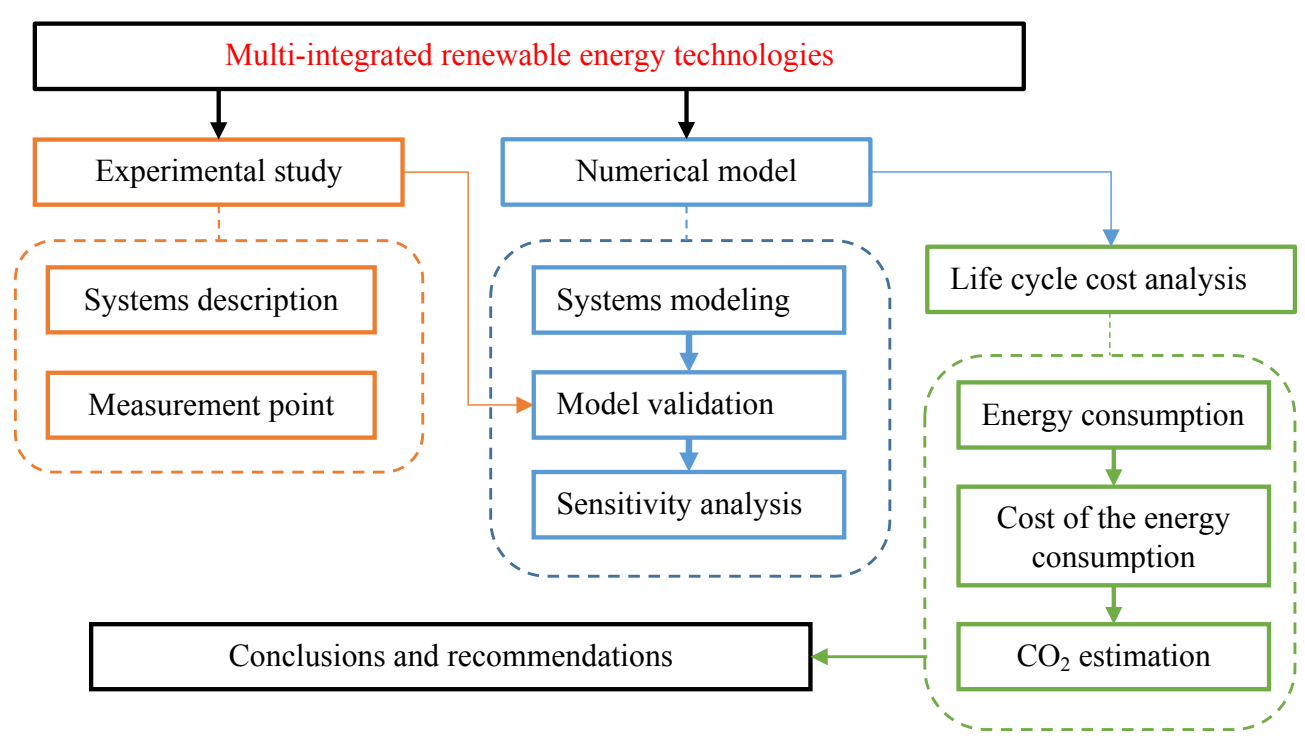

Fig. 2. Conceptual study plan.

coordinates are: $35.65^{\circ} \mathrm{N}, 0.62^{\circ} \mathrm{W}$, with north-south orientation, as shown Fig. 3. The test cell consists of two juxtaposed rooms of identical dimensions: $4.7 \times 3.7 \times 2.8 \mathrm{~m}^{3}$. The physical properties of the materials constituting are presented in Table 1 .

As shown in Fig. 3, the experimental facility consists of two rooms. Room (1) is equipped with an EAHE of a $20 \mathrm{~m}$ pipe, buried at $2 \mathrm{~m}$ in the ground and driven by a fan blowing a flow rate of $90 \mathrm{~m}^{3} / \mathrm{h}$. It is also equipped with a floor heating coupled with an UNT of $4 \mathrm{~m}^{3}$, as illustrated in Fig. 4. Room (2) is used as a technical control room.

Several sensors were used to measure the outlet temperature of the water tank, the outlet temperature of the EAHE, and the indoor (in the center of the room and at a height of $1.4 \mathrm{~m}$ ) and outdoor air temperatures. Fig. 5 shows the positioning of the measurement sensors on both systems.

Table 2 shows the characteristics of the measurement sensors used.

\subsection{Numerical model}

The numerical study was conducted using the TRNSYS software which is based on the different types, resources and techniques offered by its library. Therefore, simulations were performed by combining an EAHE with the buried tank coupled to a solar thermal collector in order to reduce the heating needs. Two representative simulation models were developed. The first model focused on the integration of two geothermal systems in the building by combining an UNT with an EAHE. The model simulation was performed under the same initial conditions of the experiment. The second model (Geo-solar) takes the same configuration as described above while including a solar thermal collector in the UNT in order to optimize the heating performance of the whole system.

The optimization principle diagram of the Geo-solar thermal installation implemented in the TRNSYS software is shown in Fig. 6. We offer in the following sub-sections the mathematical models of each system.

Table 3 present the parameters used in the simulation:

\subsubsection{UNT model}

The UNT System is modelled by associating type 38 with type 711 . The association between these components allows modelling the thermal behavior of a water storage tank buried in the ground. The ground temperature for different burial depths of the tank is modelled using the Kusuda correlation. It is used to calculate temperature profiles in undisturbed soil at different depths. The model is based on the theory of thermal conduction applied to a semi-infinite homogeneous solid. The equation that provides soil temperatures at different depths is given as follows:

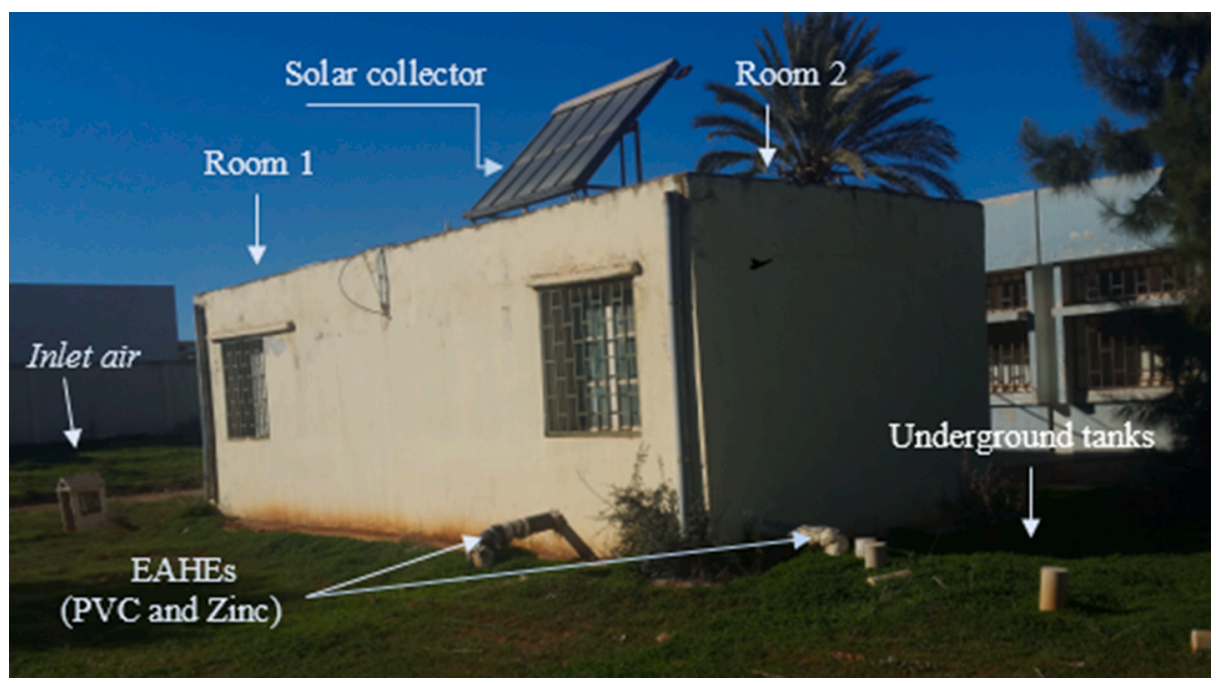

Fig. 3. Experimental cell. 
Table 1

Thermophysical properties of the different material layers of the cell.

\begin{tabular}{|c|c|c|c|c|c|c|}
\hline Composition & $\begin{array}{l}\text { Thickness } \\
(\mathrm{m})\end{array}$ & $\begin{array}{l}\text { Conductivity (W/m. } \\
\mathrm{K})\end{array}$ & $\begin{array}{l}\text { Density }(\mathrm{kg} / \\
\left.\mathrm{m}^{3}\right)\end{array}$ & $\begin{array}{l}\text { Heat capacit }(\mathrm{J} / \mathrm{kg} \text {. } \\
\mathrm{K})\end{array}$ & $\begin{array}{l}\text { Thermal transmittance } \mathrm{W} / \mathrm{m}^{2} \text {. } \\
\mathrm{K} \text { ) }\end{array}$ & $\begin{array}{l}\text { Thermal resistance }\left(\mathrm{m}^{2} \mathrm{~K}\right. \\
\left.\mathrm{W}^{-1}\right)\end{array}$ \\
\hline \multicolumn{7}{|l|}{ Vertical walls } \\
\hline Cement plaster & 0.01 & 1.5 & 1500 & 1000 & 15 & 0.0066 \\
\hline Wall first brick & 0.1 & 0.476 & 690 & 900 & 4.76 & 0.21 \\
\hline Polystyrene insulation & 0.032 & 0.039 & 25 & 1380 & 1.21 & 0.82 \\
\hline Wall second brick & 0.1 & 0.476 & 690 & 900 & 4.76 & 0.21 \\
\hline Cement plaster & 0.01 & 1.5 & 1500 & 1000 & 15 & 0.0066 \\
\hline \multicolumn{7}{|l|}{ Ceiling } \\
\hline $\begin{array}{l}\text { Tightness and external } \\
\text { mortar }\end{array}$ & 0.05 & 0.04 & 1150 & 1000 & 0.8 & 1.25 \\
\hline Polystyrene insulation & 0.04 & 0.039 & 25 & 1380 & 0.51 & 0.51 \\
\hline Compression slab & 0.04 & 1.75 & 2300 & 1000 & 43.75 & 0.022 \\
\hline Hollow body & 0.16 & 1.14 & 1850 & 1000 & 7.125 & 0.140 \\
\hline Plaster & 0.02 & 0.42 & 1200 & 837 & 2.1 & 0.047 \\
\hline \multicolumn{7}{|l|}{ Floor heating } \\
\hline Gerflex coating & 0.003 & 0.31 & 1.046 & 1190 & 103.33 & 0.009 \\
\hline Concrete & 0.1 & 1.75 & 0.92 & 2300 & 17.5 & 0.057 \\
\hline Cross-linked tube & $18 / 20\left[10^{-3}\right]$ & & & & & \\
\hline Concrete & 0.1 & 1.75 & 0.92 & 2300 & 17.5 & 0.057 \\
\hline Insulation & 0.04 & 0.039 & 1.45 & 20 & 0.975 & 1.025 \\
\hline Concrete & 0.1 & 1.75 & 0.92 & 2300 & 17.5 & 0.057 \\
\hline
\end{tabular}
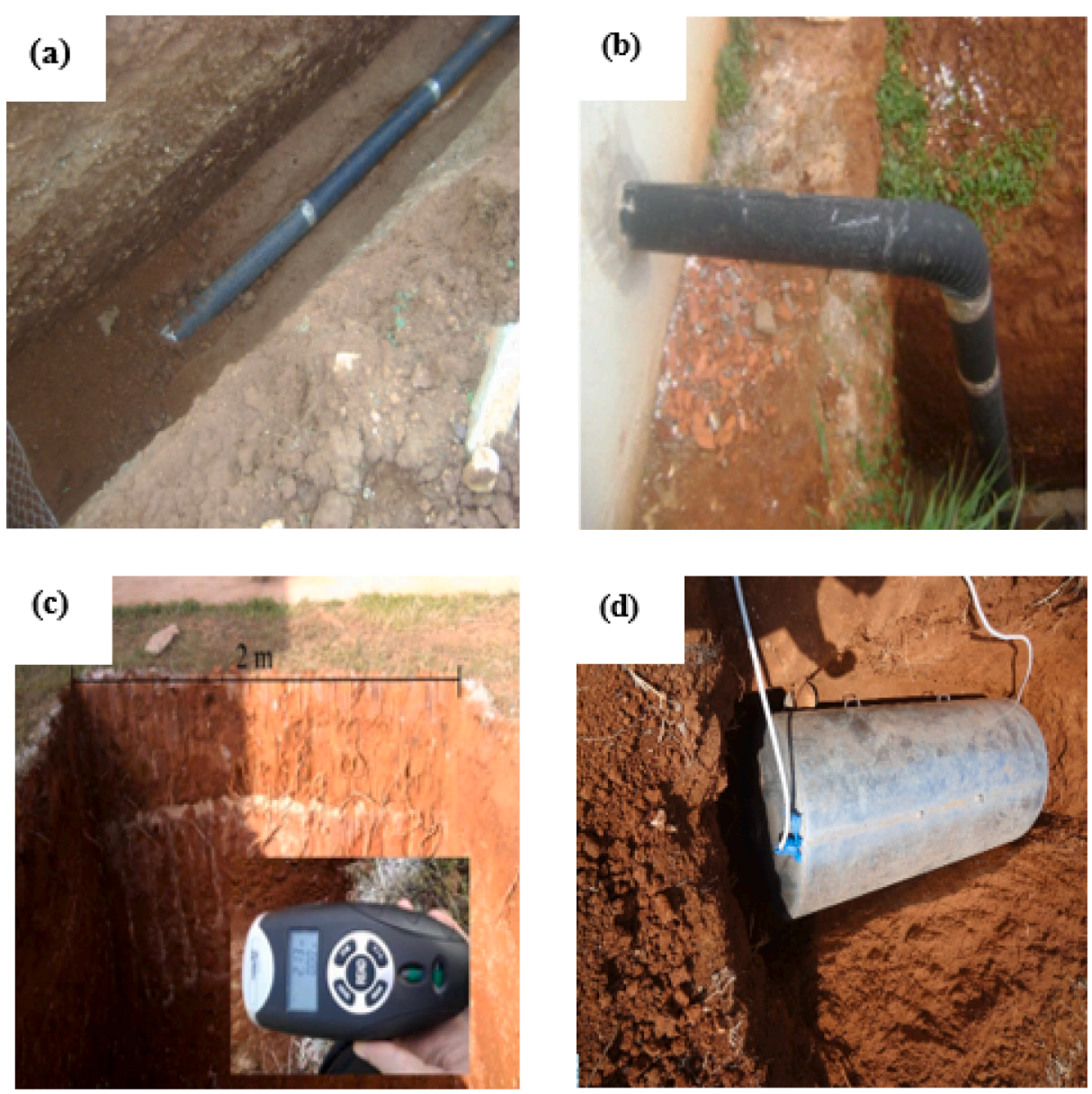

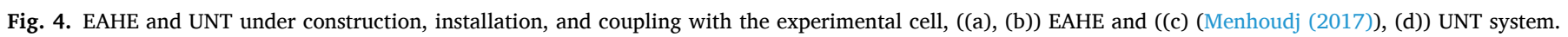

$$
\begin{aligned}
T(Z, t)= & T_{m}-A_{s} \exp \left(-Z\left(\frac{\pi}{365 \delta_{s}}\right)^{1 / 2}\right) \operatorname{Cos}\left[\frac { 2 \pi } { 3 6 5 } \left(\left(t-t_{o}\right)\right.\right. \\
& \left.\left.-\frac{Z}{2}\left(\frac{365}{\pi \alpha_{s}}\right)^{1 / 2}\right)\right]
\end{aligned}
$$

where $Z$ is the soil depth (m), $t$ is the time (hour), $t_{0}$ is the time of year with minimum soil surface temperature (hour), $T_{m}$ is the mean surface temperature $\left({ }^{\circ} \mathrm{C}\right), A_{s}$ is the amplitude of soil surface temperature throughout the year $(\mathrm{K})$, and $\delta_{s}$ is the soil thermal diffusivity $\left(\mathrm{m}^{2} / \mathrm{s}\right)$.

The energy balance on a water node takes into account storage losses from the tank and conduction between segments, and this is written as follows (TRNSYS 16, 2005): 


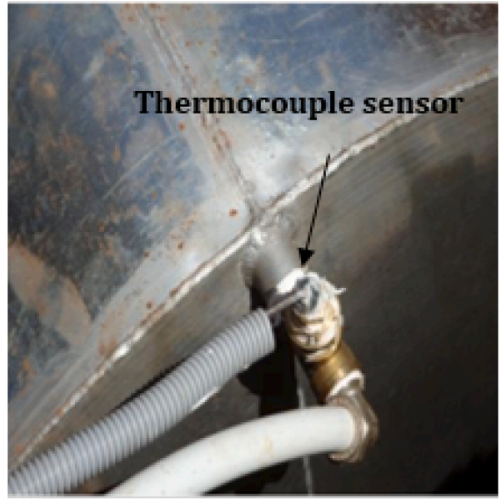

(a)

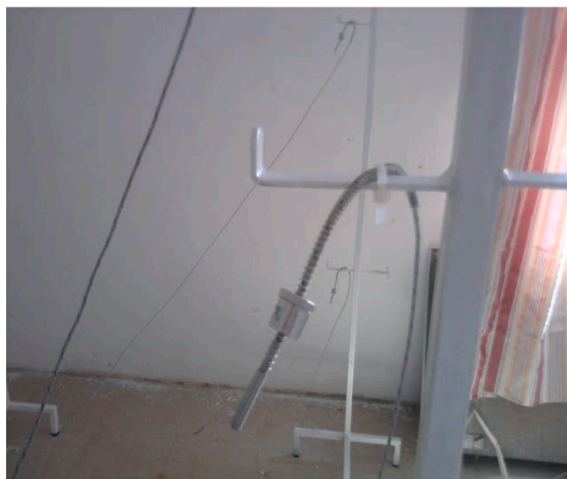

(c)

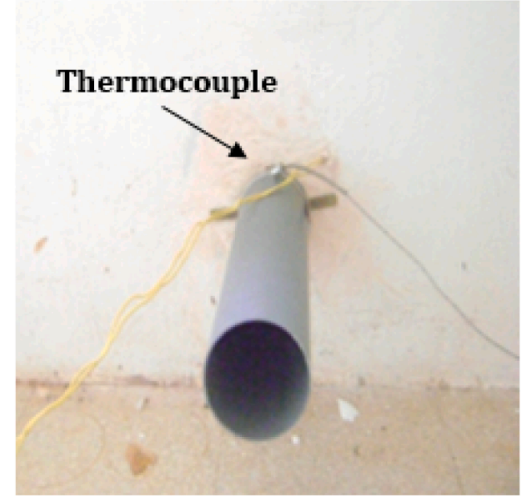

(b)

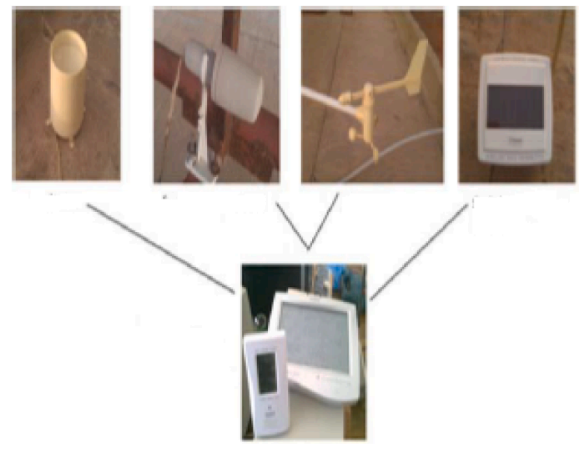

(d)

Fig. 5. Location of the thermocouples: (a) outlet temperature of the water tank, (b) outlet temperature of the EAHE, (c) the indoor air temperature (d) climatic conditions (Menhoudj (2017)).

Table 2

Wireless sensor characteristics.

\begin{tabular}{lllll}
\hline $\begin{array}{l}\text { Measured } \\
\text { parameter }\end{array}$ & $\begin{array}{l}\text { Measuring range } \\
\text { (Plage de } \\
\text { mesure) }\end{array}$ & $\begin{array}{l}\text { Accuracy } \\
\text { (Précision) }\end{array}$ & Type of sensor & Units \\
\hline Temperature & $\begin{array}{l}-40{ }^{\circ} \mathrm{C}<\mathrm{t}^{\circ}< \\
+375^{\circ} \mathrm{C}\end{array}$ & $\pm 1,5^{\circ} \mathrm{C}$ & Thermocouple & ${ }^{\circ} \mathrm{C}$ \\
$\begin{array}{l}\text { Outdoor } \\
\text { temperature }\end{array}$ & $-40 \mathrm{C} \_60 \mathrm{C}$ & $\pm 1{ }^{\circ} \mathrm{C}$ & $\begin{array}{l}\text { weather } \\
\text { station }\end{array}$ & ${ }^{\circ} \mathrm{C}$ \\
\hline
\end{tabular}

$\rho_{w} C_{p, w} V_{i} \frac{d T_{i}}{d t}=-(U A)_{i}\left(T_{i}-T_{e n v}\right)+(k A)_{i-1} \frac{\left(T_{i-1}-T_{i}\right)}{\Delta h_{i-1}}-(k A)_{i} \frac{\left(T_{i}-T_{i+1}\right)}{\Delta h_{i+1}}$

where $T_{i}$ is the segment temperature $\left({ }^{\circ} \mathrm{C}\right), \rho_{w}$ is the water density $(\mathrm{kg} /$ $\left.\mathrm{m}^{3}\right), C_{p, w}$ is the heat capacity of water $(\mathrm{J} / \mathrm{kg} \mathrm{K}), U A$ is the overall loss coefficient (W/k), $T_{e n v}$ is the environmental temperature and $\Delta h$ is the separation between centers of segments.

The total loss from the tank is written as follows:

$\dot{Q}_{e n v}=\sum_{i=1}^{N}(U A)_{i}\left(T_{i}-T_{e n v}\right)$

The energy input to the tank due to the hot inlet flow is given as follow:

$\dot{Q}_{i n}=\dot{m}_{h} C_{p, w}\left(T_{h}-T_{R}\right)$

where $T_{h}$ is the temperature of hot fluid entering tank $\left({ }^{\circ} \mathrm{C}\right)$ and $T_{R}$ is the temperature of fluid return to heat source $\left({ }^{\circ} \mathrm{C}\right)$.

\subsubsection{EAHE model}

The EAHE system was modelled by linking Type 711 with type 31 . The connection between these two components models a pipe buried horizontally in the ground and the heat exchange between them. The air circulation in the pipe is ensured by the type $3 \mathrm{c}$, which reconstitutes the fan operation. The model is solved by the finite difference method with a fully implicit scheme. For the most accurate, the radial mesh used in the simulation is $0.02 \mathrm{~m}$. This value was adjusted after performing a mesh test on the model.

The heat flux transferred by air flowing through a buried pipe can be written as:

$\dot{Q}_{\text {air }}=\dot{m}_{\text {air }} C_{p, \text { air }}\left(T_{\text {air }, \text { out }}-T_{\text {air }, \text { in }}\right)$

where $\dot{m}_{\text {air }}$ is the air mass flow rate $(\mathrm{kg} / \mathrm{s}), T_{\text {air,out }}$ is the air temperature at the outlet of the EAHE $\left({ }^{\circ} \mathrm{C}\right)$ and $T_{\text {air.in }}$ is the air temperature at the inlet of the EAHE $\left({ }^{\circ} \mathrm{C}\right)$.

The Heat flux transferred by air is equal to convection heat flux from the surface of the pipe, and it is given as follows:

$\dot{Q}_{\text {air }}=h A_{\text {pipe }} \Delta T_{l n}$

where $h$ is the convective heat transfer coefficient at the inner surface of EAHE pipe (W/m $\left.\mathrm{m}^{2} \mathrm{~K}\right), A_{\text {pipe }}$ is the inside surface of the pipe $\left(\mathrm{m}^{2}\right)$ and $\Delta T_{l n}$ is the logarithmic temperature $\left({ }^{\circ} \mathrm{C}\right)$.

$\Delta T_{l n}=T_{\text {air }, \text { out }}-T_{\text {air }, \text { in }}$

Solving equation for $T_{\text {air,out }}$ results to:

$T_{\text {air }, \text { out }}=T_{\text {wall }}+\left(T_{\text {air }, \text { in }}-T_{\text {wall }}\right) e^{\frac{h_{\text {pipe }} C_{\text {pair }}}{m_{\text {air }}}}$ 


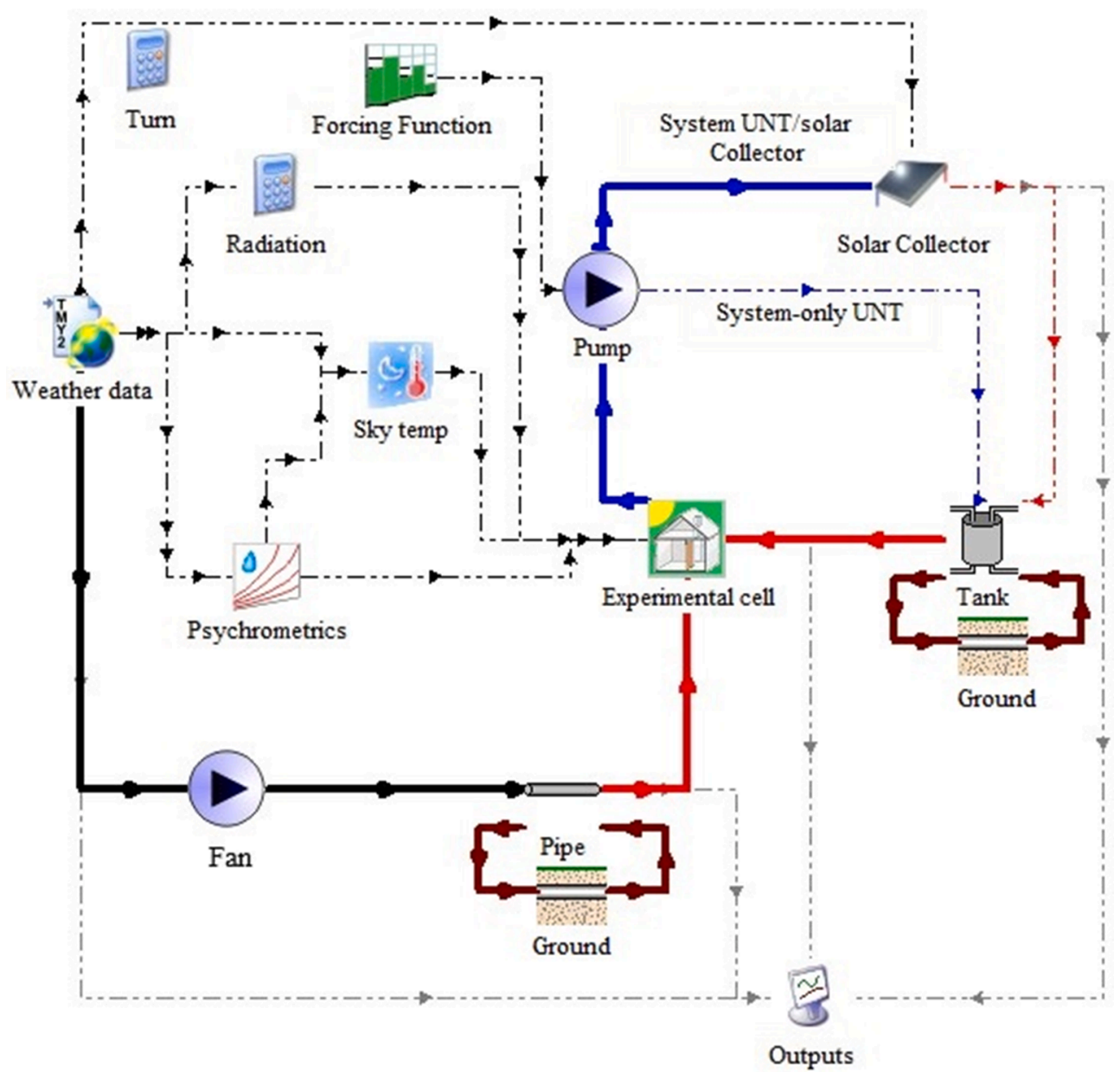

Fig. 6. Simulation flow chart in TRNSYS space.

Table 3

Parameters used in the simulation.

\begin{tabular}{|c|c|c|c|}
\hline Type 38 (Tank) & Type 711 (Ground) & Type 31 (pipe) & $\begin{array}{l}\text { Type 2b (solar } \\
\text { collector) }\end{array}$ \\
\hline $\begin{array}{l}\text { The total volume of } \\
\text { the tank: } 2000 \mathrm{~L}\end{array}$ & $\begin{array}{l}\text { The burial depth of } \\
\text { the tank: } 2 \mathrm{~m} \text {. }\end{array}$ & $\begin{array}{l}\text { Pipe length } 20 \\
\text { m }\end{array}$ & Area : $4.6 \mathrm{~m}^{2}$ \\
\hline $\begin{array}{l}\text { The thermal } \\
\text { conductivity of the } \\
\text { tank (galvanized } \\
\text { sheet): } 48 \mathrm{~W} / \mathrm{m} \text {. } \\
\text { K. }\end{array}$ & $\begin{array}{l}\text { The thermal } \\
\text { conductivity of the } \\
\text { soil: } 1.5 \mathrm{~W} / \mathrm{m} . \mathrm{K}\end{array}$ & $\begin{array}{l}\text { Pipe diameter } \\
120 \mathrm{~mm}\end{array}$ & inclination $45^{\circ}$ \\
\hline $\begin{array}{l}\text { The thermal } \\
\text { conductivity of the } \\
\text { water: } 0.6 \mathrm{~W} / \mathrm{m} \text {. } \\
\mathrm{K}\end{array}$ & $\begin{array}{l}\text { The heat capacity of } \\
\text { the soil: } 920 \mathrm{~J} / \mathrm{kg} \text {. } \\
\mathrm{K} \text {. }\end{array}$ & $\begin{array}{l}\text { Pipe thickness } \\
4 \mathrm{~mm}\end{array}$ & $\begin{array}{l}\text { South } \\
\text { orientation }\end{array}$ \\
\hline $\begin{array}{l}\text { Mass heat of water } \\
\text { (Cp): } 4,18 \mathrm{~kJ} / \mathrm{kg} \text {. } \\
\mathrm{K}\end{array}$ & $\begin{array}{l}\text { Average surface } \\
\text { temperature: } 20^{\circ} \mathrm{C} .5 \\
\text { Thickness of radial } \\
\text { node: } 0.1 \mathrm{~m}\end{array}$ & $\begin{array}{l}\text { Total heat } \\
\text { transfer } \\
\text { coefficient U } \\
1.976 \mathrm{~W} / \mathrm{m} . \mathrm{K}\end{array}$ & $\begin{array}{l}\text { Mass heat of } \\
\text { water }(\mathrm{Cp}) \text { : } \\
4,18 \mathrm{~kJ} / \mathrm{kg} . \mathrm{K}\end{array}$ \\
\hline
\end{tabular}

where $T_{\text {wall }}$ is the pipe wall temperature $\left({ }^{\circ} \mathrm{C}\right)$.

\subsubsection{Solar thermal collector}

The solar thermal collector is modelled using type 73. This component models the thermal performance of a theoretical flat plate collector based on the Hottel-Whillier steady-state model. The circulation of fluids inside the solar-geothermal network (collector/tank) is ensured by type $3 \mathrm{~b}$, which models the operation of a hydraulic pump. The solar collector has a surface area of $4.6 \mathrm{~m}^{2}$ with a south-facing orientation and a slope of $45^{\circ}$. Concerning the optimization of the system with the solar collector, the dimensions and thermo-physical parameters of the tank and the EAHE are not changed.

The energy received by the solar collector surface is modelled according to the Hottel-Whillier equation:

$Q_{u}=\frac{A}{N_{S}} \sum_{j=1}^{N_{S}} F_{R, j}\left(I_{T}(\tau \alpha)-U_{L, j}\left(T_{w, i, j}-T_{a}\right)\right)$

where $A$ is the total collector array aperture $\left(\mathrm{m}^{2}\right), N_{S}$ is the number of identical collectors in series, $I_{T}$ is the global radiation incident on the solar collector $\left(\mathrm{kJ} / \mathrm{h} \mathrm{m}^{2}\right), \tau \alpha$ is the product of the cover transmittance and the absorber absorptance, $U_{L}$ is the thermal loss coefficient $\left(\mathrm{W} / \mathrm{m}^{2}\right.$ $\mathrm{K}), T_{w}$ is the inlet temperature of the fluid to the collector $\left({ }^{\circ} \mathrm{C}\right), T_{a}$ is the ambient air temperature $\left({ }^{\circ} \mathrm{C}\right)$ and $F_{R}$ is the overall collector heat removal efficiency factor which is calculated by:

$F_{R, j}=\frac{N_{s} \dot{m}_{w} C_{p w}}{A U_{L, j}}\left(1-\exp \left(-\frac{F^{\prime} U_{L, j} A}{N_{s} \dot{m}_{w} C_{p w}}\right)\right)$

where $\dot{m}_{w}$ is the mass flow rate of the water flowing through the pipe $(\mathrm{kg} / \mathrm{h}), C_{p w}$ is the specific heat of the water $(\mathrm{kJ} / \mathrm{kg} \mathrm{K})$ and $F^{\prime}$ is the collector efficiency factor which is given according to the following equation:

$F^{\prime}=\frac{R_{\text {absorber-Ambiance }}}{R_{\text {Fluid-Ambiance }}}$ 


\subsubsection{Control system}

The solar thermal collector operation is controlled by a forcing controller using type 14, as shown in Fig. 7. In this study, we introduced a control strategy which allows operating the circulation pump at intermittent periods:

- Activate the solar collector - buried tank pump from 8 a.m. until 7p.m.

- Stop the solar collector pump in the evening between 7p.m. and 8 a.m.

\subsubsection{Climate description}

The thermal behavior of a building depends on external conditions such as the outdoor temperature, outdoor humidity, and solar radiation with its environment. Assessment of soil and solar thermal potential is essential for the Geo-solar system. It depends heavily on meteorological and in situ conditions. The energy efficiency of the system is proposed for Oran city. Oran is a city in the northwest of Algeria. It enjoys a perfect Mediterranean climate (temperate climate) characterized by hot and dry summers and mild and humid winters with an average annual winter temperature varying around $14.2{ }^{\circ} \mathrm{C}$. The minimum and maximum average temperatures as well as the global solar radiation of Oran city are represented in Table 4.

\subsection{Model validation and calibration}

The indoor air temperature measured during the test period was compared with that obtained by simulation. Experimental studies usually involve unpredictable and uncertain factors that occur due to instrumental, calibration, and human measurement errors. These uncertainties may be calculated using statistical analysis through recognized formulae. For this, the error analysis of the thermal model performance of the experimental cell integrating all systems was calculated by comparing its results with the experimental data. The simulation is carried out with a time interval of $1 \mathrm{~h}$, which is equal to the monitoring time step of the experiment. In this study, the mean square error (MSE), the mean absolute error (MAE) and the relative error (RE) were calculated. They are defined as follows:

$$
\begin{aligned}
& \text { MSE }=\frac{1}{N} \sum_{\mathrm{K}-1}^{\mathrm{N}}\left(\mathrm{y}^{\prime}-\mathrm{y}\right)^{2} \\
& \mathrm{MAE}=\frac{1}{\mathrm{~N}} \sum_{\mathrm{K}-1}^{\mathrm{N}}\left|\mathrm{y}^{\prime}-\mathrm{y}\right| \\
& \mathrm{RE}=\left(\frac{\sum_{\mathrm{i}=1}^{\mathrm{N}}\left|\mathrm{y}^{\prime}-\mathrm{y}\right| / \mathrm{y}^{\prime}}{\mathrm{N}}\right) \times 100
\end{aligned}
$$

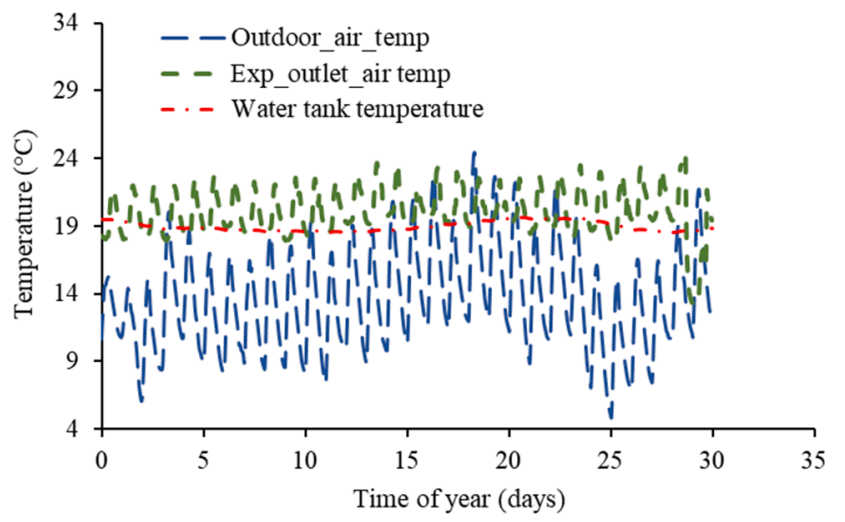

Fig. 7. Temperature variations of outdoor air underground water tank (UNT), and air at the outlet of the EAHE, for December.
Table 4

Average monthly ambient air temperature of the Oran region (Algerian National Weather Office).

\begin{tabular}{lllll}
\hline Month & $\begin{array}{l}\text { Mean daily } \\
\text { minimum } \\
\text { temperature } \\
\left({ }^{\circ} \mathrm{C}\right)\end{array}$ & $\begin{array}{l}\text { Mean daily } \\
\text { maximum } \\
\text { temperature } \\
\left({ }^{\circ} \mathrm{C}\right)\end{array}$ & $\begin{array}{l}\text { Mean global } \\
\text { horizontal } \\
\text { radiation }(\mathrm{W} / \\
\left.\mathrm{m}^{2}\right)\end{array}$ & $\begin{array}{l}\text { Mean total } \\
\text { precipitation }\end{array}$ \\
\hline Jan & 5.1 & 16.6 & 122 & 43.6 \\
Feb & 6.5 & 17.7 & 151 & 44.4 \\
Mar & 8.1 & 19.7 & 201 & 35 \\
Apr & 10 & 21.5 & 251 & 29.6 \\
May & 13.2 & 23.9 & 292 & 27.2 \\
Jun & 16.9 & 27.7 & 320 & 3.8 \\
Jul & 19.4 & 30.5 & 333 & 1.8 \\
Aug & 20.1 & 31.6 & 293 & 2.7 \\
Sep & 17.7 & 29 & 233 & 13.2 \\
Oct & 14 & 25.2 & 178 & 24.8 \\
Nov & 9.5 & 20.6 & 134 & 55.5 \\
Dec & 6.7 & 17.7 & 109 & 45.2 \\
\hline
\end{tabular}

where $y$ is the measured variables, $y$ is the predicted variables, and $N$ is the number of samples.

\subsection{Sensitivity analysis}

In order to identify the factors that influence the thermal performance of the Geo-solar system, two steps sensitivity analysis is performed. It consists of: (1) the variation of the solar thermal collector surface to optimize the solar capture, and, (2) the variation of the storage volume for a good compromise between the solar thermal collector surface and the storage volume. In the first step, only the surface parameter of the solar thermal collector was varied. Otherwise, all the other simulation conditions were maintained as in the experiment $\left(4 \mathrm{~m}^{3}\right.$ volume and EAHE configuration is the same). In the second, the storage volume parameter is only varied. However, the solar collector surface remains constant $\left(S=4.6 \mathrm{~m}^{2}\right.$ ). Table 5 presents the two case studies concerning the parameters of the storage tank volume and the solar thermal collector surface.

\subsection{Cost calculation method}

The building heating energy consumption depends on the system, operating time, and climatic conditions. In this context, Ghedamsi et al. (2016) estimated the cost of annual energy consumption for different regions of Algeria. They delineated the climatic zone in seven sub-zones according to use and cost. Algeria is a major producer of natural gas, and boiler heating is the most used technique in this country. According to the World Energy Statistical Review of 2018, Algeria's domestic energy consumption was approximately 2.1 quadrillion British thermal units in 2017 (Table 6).

In order to highlight the economic benefit (consumption cost) and the environmental impact (CO2 emission) of this paper, we present a comparative study between the Geo-solar and the conventional heating system, i.e. the gas boiler.

The power consumption of the Geo-solar system depends on the pump $(60 \mathrm{~W})$ and the fan $(40 \mathrm{~W})$. In a study conducted by Lekhal et al. (2019), the thermal comfort ratio was evaluated for a residential building integrating a Direct Solar Floor combined with an EAHE. In fact, this ratio represents the thermal comfort hours above the set point of $21{ }^{\circ} \mathrm{C}$ (DTR, 2011). In our study, we re-used these thermal comfort

Table 5

Sensitivity Analysis.

\begin{tabular}{lll}
\hline Case study & 1 & 2 \\
\hline Step 1: Solar collector area & $4.6 \mathrm{~m}^{2}$ & $2.6 \mathrm{~m}^{2}$ \\
Step 2: Storage volume & $4 \mathrm{~m}^{3}$ & $2 \mathrm{~m}^{3}$ \\
\hline
\end{tabular}


Table 6

Energy consumption by fuel source in Algeria, 2017 (US. Energy Information Administration).

\begin{tabular}{llll}
\hline & Naturel gas (\%) & Oil (\%) & Total (BTUs) \\
\hline Energy consumption & 37 & 63 & 2.1 \\
\hline
\end{tabular}

hour ranges to evaluate the system's energy consumption.

According to Algeria Electricity, the electricity price per $\mathrm{kWh}$ is $0.03473 €$ and that of natural gas is $0.074 €$ per $\mathrm{kWh}$.

The consumption cost per heating period is calculated as follows:

Price per $k W h \times$ power $(k W) \times$ Thermal comfort hours (hours)

\section{Results}

In this section, the thermal performance of the geothermal system combining the UNT with the EAHE as well as its optimization (Geo-solar system) by loading the UNT by a solar thermal collector are presented. Firstly, we present the experimental and numerical results obtained by the combination between UNT and EAHE. Then, we expose the numerical results of the Geo-solar system including the EAHE, the UNT optimized by the solar thermal collector.

\subsection{Geothermal system combining (UNT with EAHE子}

\subsubsection{Experimental results}

For 30 days of December 2016, we monitored the outdoor air, water tank (UNT) and outlet air temperatures of the EAHE, as shown in Fig. 7. The temperatures of UNT and EAHE are higher than those of the outdoor air. They vary from 18.3 to $20^{\circ} \mathrm{C}$ for UNT and 18.3 to $24^{\circ} \mathrm{C}$ for EAHE, while those for the outdoor air range from 4 to $24^{\circ} \mathrm{C}$. The temperature gain provided by these systems can be up to $14^{\circ} \mathrm{C}$.

Fig. 8 shows the experimental evolution of the indoor air temperature in the test cell. It varies from 18 to $20^{\circ} \mathrm{C}$, while the outdoor air temperature varies from 4 to $24{ }^{\circ} \mathrm{C}$, resulting a maximum temperature difference of $16^{\circ} \mathrm{C}$.

\subsubsection{Model validation}

Fig. 9 compares the simulated and experimental indoor air temperatures of the test cell equipped with UNT and EAHE in December. As can be seen on the graph, the simulation results are in good agreement with those of the experiment. The MSE, MAE and RE of the indoor air temperature is $0.07,0.16$ and $85 \%$, respectively, as shown in Table 7 . The measured indoor air temperature varied from 18.5 to $20^{\circ} \mathrm{C}$, while the corresponding simulation results varied from $18.5^{\circ} \mathrm{C}$ to $21.6^{\circ} \mathrm{C}$. During this evolution, we observed indoor air temperature peaks obtained by simulation between fifteenth and twentieth days. This is due to the outdoor air temperature which is essentially high during these periods and which is blown by the EAHE inside the building after having

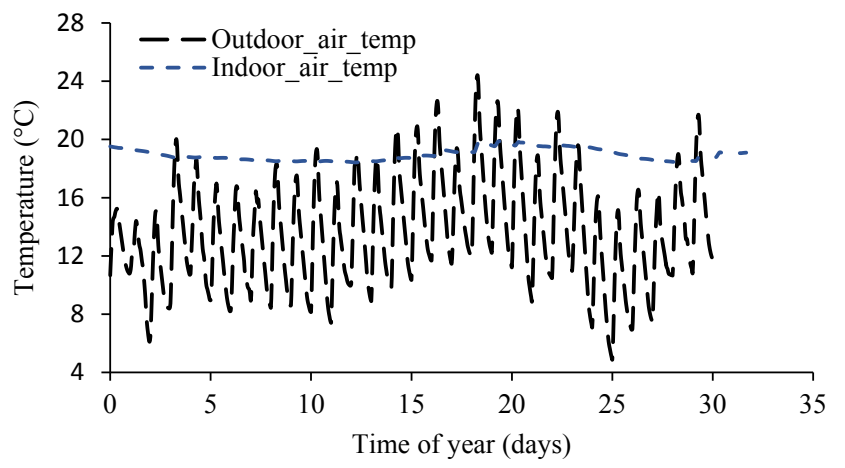

Fig. 8. Temperature variations of the outdoor air and the test cell equipped of the UNT combined with the EAHE during December.

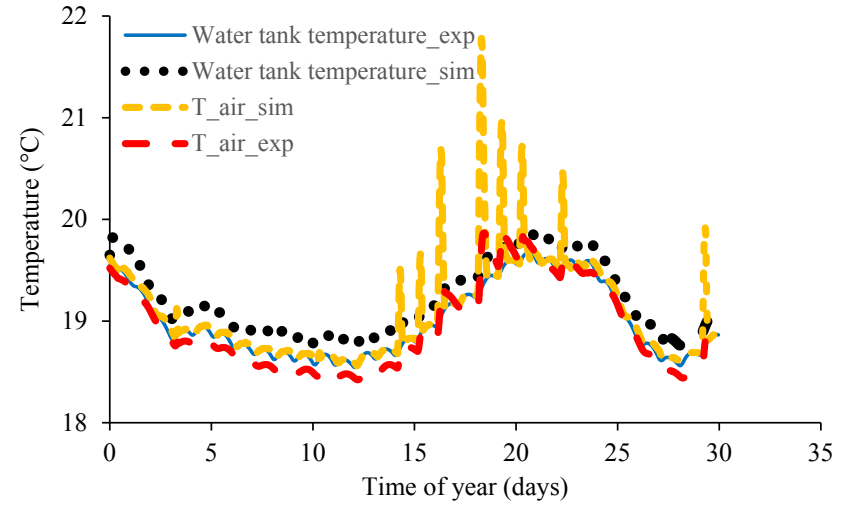

Fig. 9. Model validation, December.

Table 7

Model performance.

\begin{tabular}{llll}
\hline Parameter & MSE & MAE & RE (\%) \\
\hline T_air & 0.07 & 0.16 & 0.85 \\
Water tank temperature & 0.04 & 0.12 & 0.81 \\
\hline
\end{tabular}

exchanged heat with the ground. These temperature peaks due to the outside temperature are obvious in the simulation as opposed to the experimental one. Fig. 9, show also a comparison between experimental and simulated tank temperature. The validation shows that the simulation results are in good agreement with the experimental results. The MSE, MAE and RE of the water tank temperature is 0.040 .12 and $81 \%$, respectively, as shown in Table 7 . The measured inlet water tank temperature varies between $19.7^{\circ} \mathrm{C}$ and $18.5^{\circ} \mathrm{C}$, while the numerical model varies between $19.9^{\circ} \mathrm{C}$ and $18.7^{\circ} \mathrm{C}$.

\subsubsection{Soil-systems heat exchange}

Soil thermal behavior has a direct effect on the energy performance of geothermal systems. Fig. 10 shows the temperature variations of the water tank, the air at the outlet of the EAHE and the soil over two years of operation. The results show that the temperature difference between the soil at $2 \mathrm{~m}$ and the water tank temperature is $4.2{ }^{\circ} \mathrm{C}$ during the heating period. On the other hand, the temperature difference between the soil at $2 \mathrm{~m}$ and EAHE temperature is $1.3^{\circ} \mathrm{C}$. The results reveal that the energy input of the EAHE is lower compared to the UNT, which shows the interest of the thermal storage. Similarly, when multiple systems are combined, a more adequate and adaptive control strategy is recommended to create synergy and complementarity between these systems.

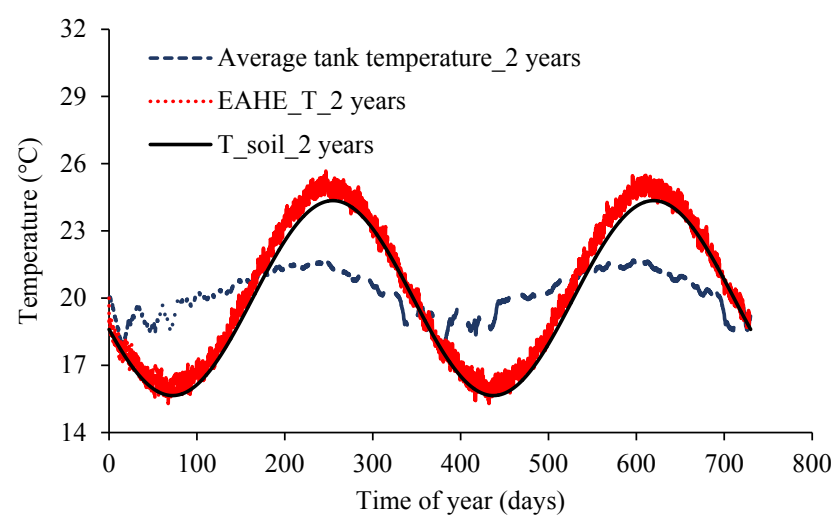

Fig. 10. Temperature variation of the water tank, the air at the outlet of the EAHE and the soil at $2 \mathrm{~m}$ depth for 2 years. 


\subsection{Geo-solar system}

\subsubsection{Thermal and energy gains}

In this section, we present the energy contribution of the EAHE and the UNT charged by the solar collector for Oran city. Fig. 11 shows the heat gain provided by the solar collector to the water tank (UNT) temperature for the month of December. For a solar collector surface of 4.6 $\mathrm{m}^{2}$, the water temperature can be as high as $42^{\circ} \mathrm{C}$. On the other hand, the water temperature without the contribution of the solar collector reaches a maximum value of $21{ }^{\circ} \mathrm{C}$. The results show that the solar thermal collector coupled to an UNT provides a temperature gain of up to $17^{\circ} \mathrm{C}$.

Furthermore, a comparative study of the indoor air temperature for a dynamic system without a source, combined geothermal system (EAHE and UNT), and a combined Geo-solar system (UNT / Solar collector + EAHE system), is exposed in Fig. 12. The results show that this reignited strategy increases the indoor air temperature by $7{ }^{\circ} \mathrm{C}$ compared to the case without a heat source and $5{ }^{\circ} \mathrm{C}$ compared to the combined geothermal system. According to these results, we recommend the use of the combined Geo-solar, taking into account the pump regulation.

Fig. 13 shows the thermal gain provided to the indoor air by the Geosolar system compared to the combined system (EAHE and UNT) and the case without sources. As shown in the graphic, the temperature gain provided by the Geo-solar system compared to the case without a source varies from 2 to $9.5^{\circ} \mathrm{C}$ and that provided by the same system compared to the combined system varies from 0 to $9.5^{\circ} \mathrm{C}$. In fact, it can be said that the Geo-solar system which is at the base a combined system optimized by the solar collector provides a thermal gain up to $9.5^{\circ} \mathrm{C}$ in the building inside compared to the combined system (EAHE + UNT).

This section shows the interest of combining the three systems compared to use them separately. The energy benefits provided by the combined Geo-solar system, UNT and by the EAHE are defined by:

$\mathrm{Qc}(\mathrm{EAHE})=\dot{\mathrm{m}}_{\text {eau }} * \mathrm{Cp}_{\mathrm{air}}{ }^{*}\left(\mathrm{~T}_{\mathrm{in}}-\mathrm{T}_{\text {out }}\right)$

$\mathrm{Qc}(\mathrm{UNT})=\dot{\mathrm{m}}_{\text {eau }} * \mathrm{Cp}_{\mathrm{water}} *\left(\mathrm{~T}_{\mathrm{in}}-\mathrm{T}_{\text {out }}\right)$

The energy supplied by each system and their coverage rates (EAHE only, UNT only and combined Geo-solar system) are shown in Fig. 14. For the month of December, the energy supplied by the combined Geosolar system is $435.4 \mathrm{KWh}$, while the energy supplied by the EAHE and UNT is 138.4 and $163.8 \mathrm{KWh}$, respectively. Concerning the coverage rate, the Geo-solar system covers the total needs with a rate of $131 \%$, while those covered by EAHE and UNT are $49.3 \%$ and $41.7 \%$, respectively.

\subsubsection{Sensitivity analysis}

The indoor air temperature is influenced by the water storage

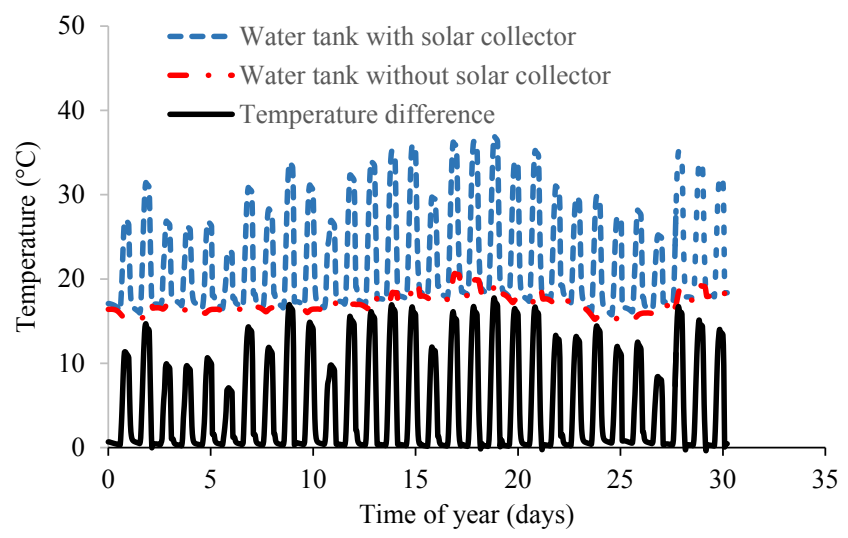

Fig. 11. The water tank temperature with and without solar thermal collector as well as the heat gain provided by the solar collector (temperature difference).

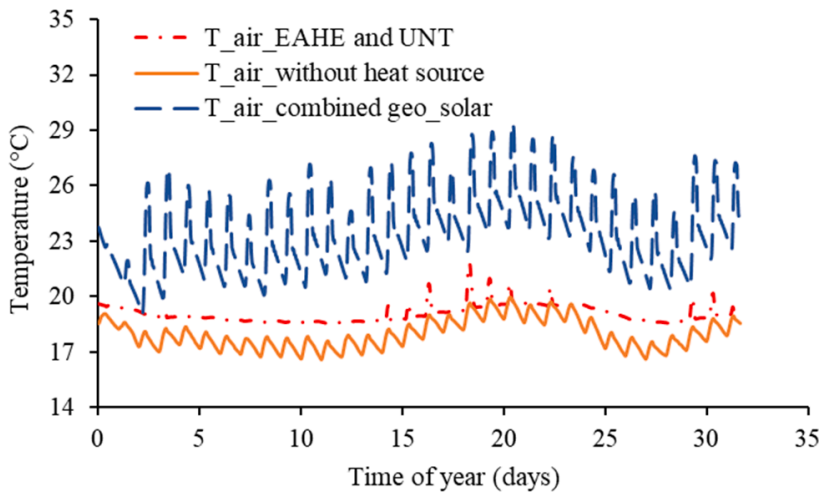

Fig. 12. Comparison of the three case studies.

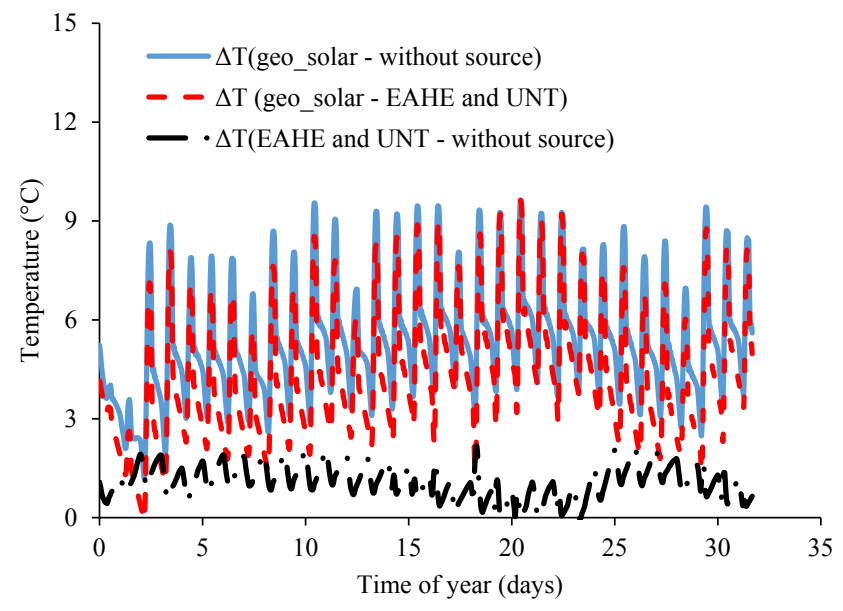

Fig. 13. Thermal gain provided to the indoor air by the Geo-solar system compared to the combined system (EAHE and UNT) and the case without sources.

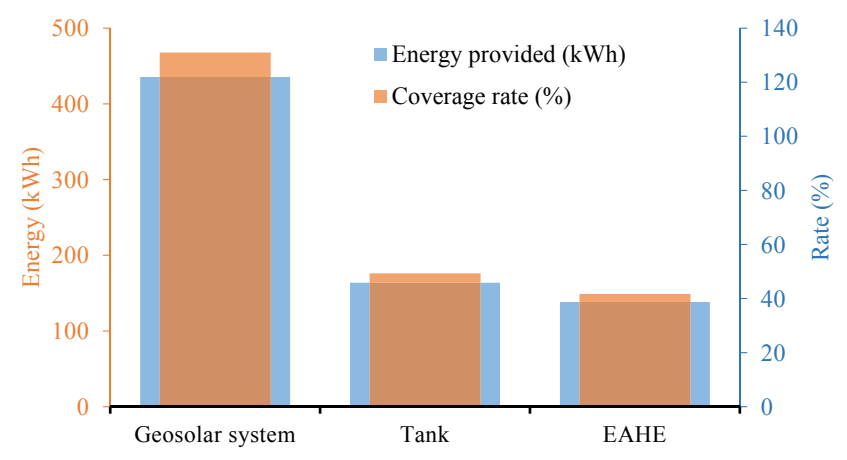

Fig. 14. Energy provided and coverage rate.

temperature and solar radiation. Based on this, the Geo-solar system has been tested for two configurations: the first one (Fig. 15) shows the surface influence of the solar collector on the indoor air temperature. Two surfaces ( $\mathrm{S}=2.6 \mathrm{~m}^{2}$ and $4.6 \mathrm{~m}^{2}$ ) have been tested for the same storage volume of $4 \mathrm{~m}^{3}$.

The variation in the area of the solar thermal collector affects the outlet water tank temperature. By reducing the surface of the solar collector, the water temperature decreases, which causes a drop in indoor temperature (Fig. 15). The temperature difference is around $3^{\circ} \mathrm{C}$.

The second configuration shows the effect of storage volume on indoor air temperature for the same solar collector surface $\left(4.6 \mathrm{~m}^{2}\right)$. 


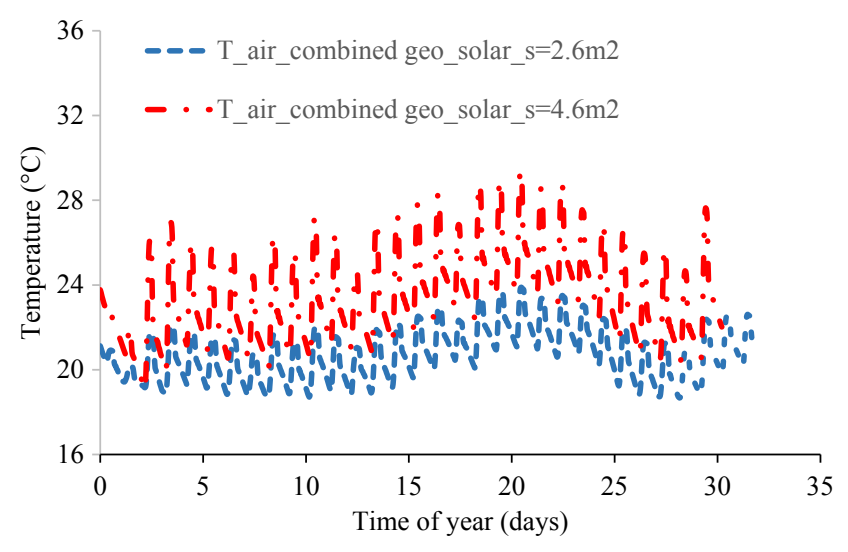

Fig. 15. Influence of the area of the solar collector on indoor air temperature.

Contrary to the results of the first configuration, the decrease in storage volume increases the temperature of the tank water, which causes an increase in indoor temperature with $2{ }^{\circ} \mathrm{C}$ (Fig. 16).

\subsubsection{Life cycle cost analysis}

In this section, energy consumption was compared for the case of the combined Geo-solar system and the boiler system. The heating power calculation of the boiler for the experimental cell was done using the program (http://quopera.e-monsite.com/pages/estimation-en-ligne/ cout-chauffage.html). The power required for the boiler is $1.94768 \mathrm{~kW}$. Fig. 17 shows the energy consumption for both systems for the period of November to January. In this section, it was found that the boiler has the highest heating energy consumption, while the Geo-solar system showed the lowest heating energy consumption. We can notice that the maximum energy consumption is recorded in December with a value of $12.6 \mathrm{kWh}$ for the Geo-solar system and $245.4 \mathrm{kWh}$ for the boiler, followed by the month of January with a cost of $11.6 \mathrm{kWh}$ for the Geosystem solar and $225.93 \mathrm{kWh}$ for the boiler. A difference of 232.8 $\mathrm{kWh}$ of consumption could be recovered thanks to our methodology.

Algeria is considered as one of the most significant emitters of $\mathrm{CO} 2$ among African countries. For this purpose, we present in Table 8 an estimate of $\mathrm{CO} 2$ emitted by the boiler and Geo-solar systems. This estimate was made using calculator CO2(calculator CO2: http://calculateurco2.org/?lang=fr\#Accueil). According to this table, it was seen the highest $\mathrm{CO} 2$ emission (Tons) by the boiler compared to the Geo-solar systems. The proposed system reduces $\mathrm{CO} 2$ emission with 21.14 tons for the whole heating period.

Fig. 18 presents the cost of energy consumption for the boiler and Geo-solar systems. A consumption cost peak is observed in December related to the electricity consumption peak seen in Fig. 20 in the order of 18.5 euros for the boiler and 0.43 euro for the Geo-solar system. The results show that the proposed system allows to reduce the energy

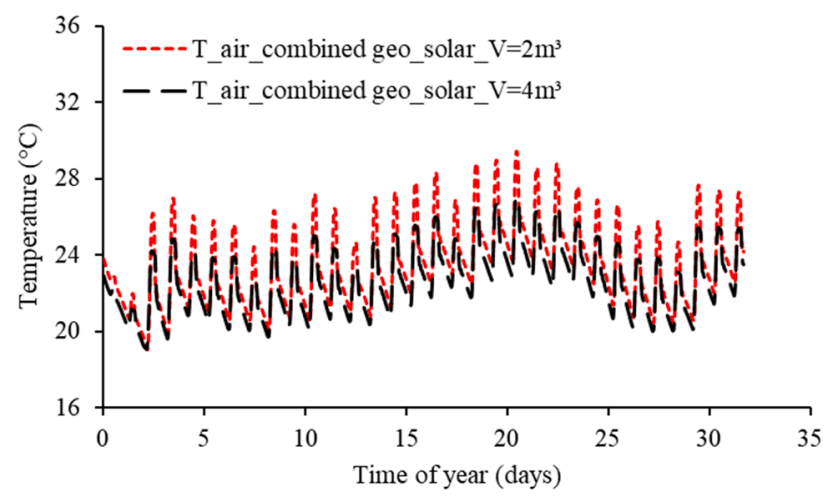

Fig. 16. Influence of the storage volume on indoor air temperature.

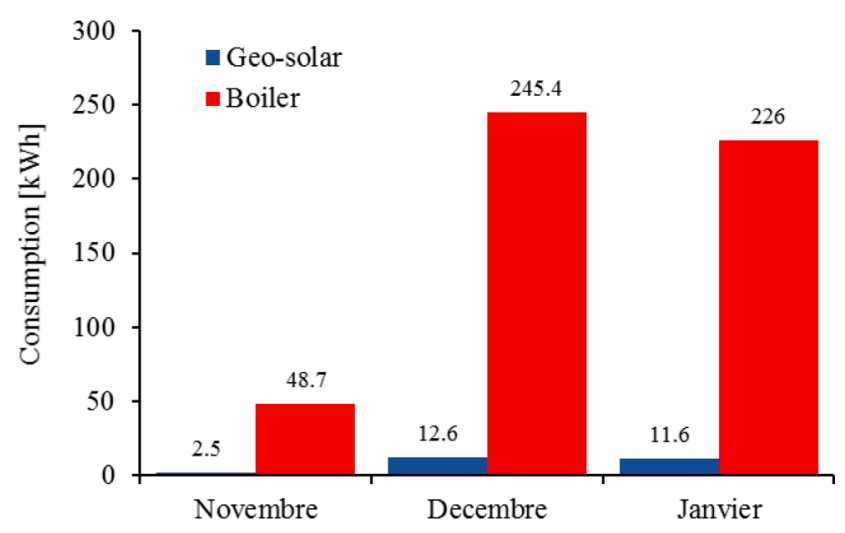

Fig. 17. Energy consumption of Geo-solar system and Boiler.

Table 8

CO2 estimated for both systems.

\begin{tabular}{llll}
\hline CO2 emission (Tons) & November & December & January \\
\hline Geo-solar & 0 & 0.01 & 0.01 \\
Boiler & 1.96 & 10 & 9.2 \\
\hline
\end{tabular}

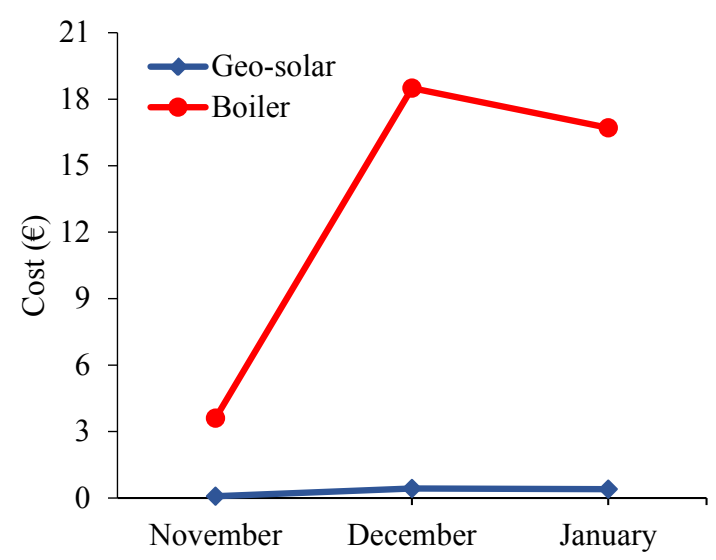

Fig. 18. Cost of the energy consumption of Geo-solar system and Boiler.

consumption cost about 37.9 euros for the whole heating period.

\section{Discussion}

\subsection{Summary of major findings and recommendations}

In this study, we developed an experimental and numerical study of the thermal performance of a system integrating solar and geothermal as an energy source for NZEBs in the Mediterranean context.

In the same view and context, several studies were conducted such as EAHE for cooling studied by Menhoudj et al. (2018), Direct Solar Floor by Lekhal et al. (2019), seasonal storage for cooling by Benzaama et al. (2019) and EAHE for heating by Lekhal et al. (2021). Our research strategy shows the advantage of combining and integrating several renewable energy systems in the building in order to cover heating and cooling needs.

The thermal solar energy storage is one of the promising techniques that has not yet been widely developed in northern Algeria. Thus, according to the current state of the art, the combination of EAHE and seasonal storage assisted by solar energy has not been developed yet for the Mediterranean context. The most important and tangible results of our system's performance are listed as follows: 


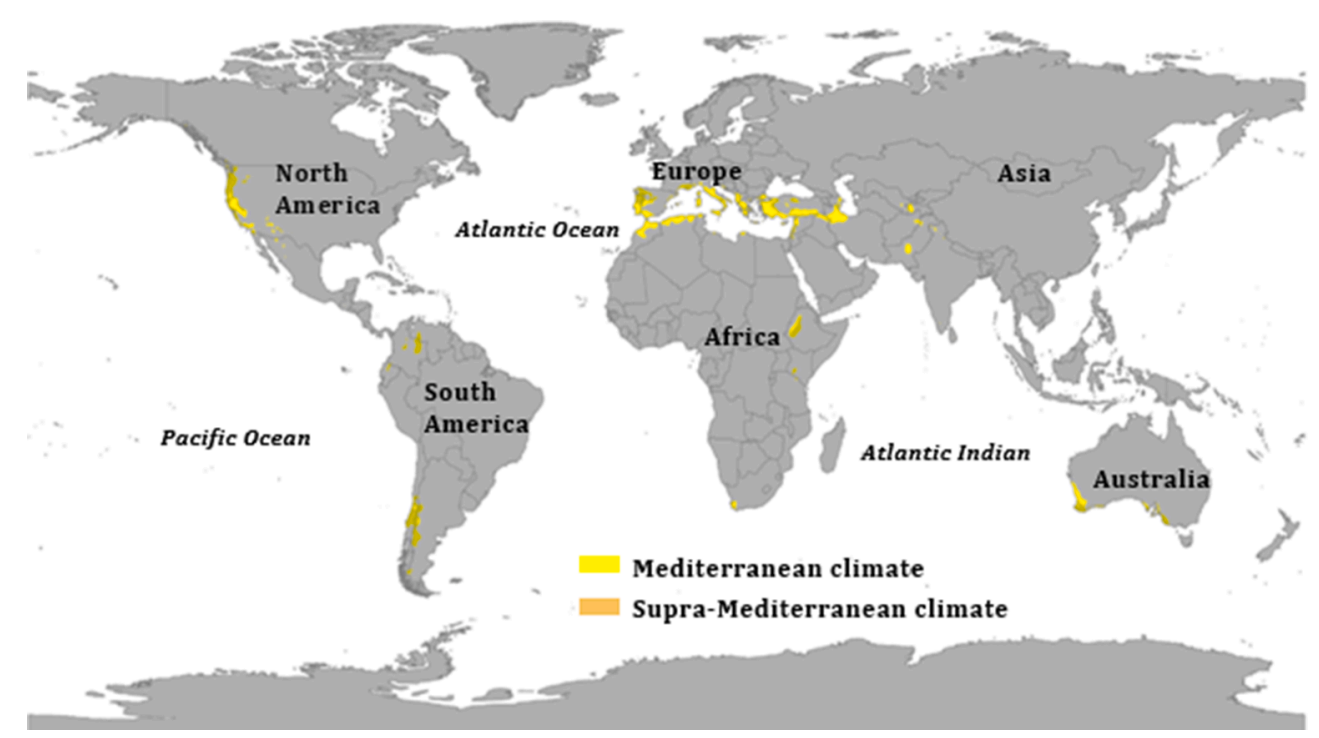

Fig. 20. Mediterranean climate covering different geographical regions of the world [Modified from (Peel et al., 2011)].

- Temperature ranges between water tank without solar thermal charging and soil is around $4.2{ }^{\circ} \mathrm{C}$.

- The use of the EAHE and the UNT charged by thermal solar collector increases the indoor air temperature of $7{ }^{\circ} \mathrm{C}$ compared to the experimental cell without source.

- The Geo-solar system covers all needs with a coverage rate of $131 \%$. The coverage rate provided by the EAHE and UNT systems is $49.3 \%$ and $41.7 \%$, respectively. The surplus gain could be used for domestic hot water.

- The sensitivity analysis allowed to quantify the influence of the different parameters and their effects on the indoor air temperature. The good sizing of the system depends mainly on the solar collector surface and the tank storage volume.

- Particular attention must be paid to the energy consumption, cost and $\mathrm{CO} 2$ emissions. Combining three systems can save $232.8 \mathrm{kWh}$ and $37.9 €$ for the whole heating period, which can avoid 21.14 tons of $\mathrm{CO} 2$ emissions.

\subsection{Study strength and limitations}

The strength of the study is the use of a full-scale experimental cell coupled to different energy systems. The developed models were validated against the experimental data provided by the combined system (UNT and EAHE) integrated in the experimental cell under the climatic conditions of Oran. This study is the first to propose a nearly zero energy building by combining three different renewable systems for Algeria's Mediterranean climate, contrary to the above-mentioned research which only focused on a single system. Thus, this research aimed to encourage the simultaneous use of solar and geothermal deposits in the Mediterranean climate and to reduce the use of conventional systems such as gas boilers.

Consequently, our study can be interpolated to other regions characterized by a Mediterranean climate such as North Africa, Southern Europe (France, Italy, etc.), North-East Spain and North Asia. In Fig. 20, we present an overview of the different world regions sharing the same Mediterranean climate, from which the system proposed in this paper can be referenced. Furthermore, we believe that our study can serve as a basis for promoting the integration of renewable energies in Algeria's building sector.

Finally, the paper proposes a new application for building heating which can be considered as a new contribution to literature and civil engineering. Nevertheless, we are aware that our study has limitations as any other. In fact, the experimental study was conducted only on the combined geothermal system (UNT and EAHE) and the optimization part concerning the coupling of UNT with the solar thermal collector was performed via numerical modelling. Moreover, the data monitoring was carried out only in December. The measurement campaign could have benefited from a longer monitoring period covering the whole winter season. Nevertheless, we conducted our study using the most appropriate data.

\subsection{Implications on practice and future research}

The implication of these results showed the importance of combining different renewable systems such as an EAHE, a UNT and a solar thermal collector to cover heating needs. Thus, it also allows a progressive evolution towards the application of NZEBs in Algeria. Moreover, this study provides building thermal engineers with some preliminary information on such a system in order to better undertake its implementation, whether in the context of the Mediterranean climate in general or that of Algeria in particular. Another important implication of our study is that it calls for the valorization of the solar deposit, which has Algeria to replace the conventional heating system such as the boiler. We find it essential that the National Building Efficiency Standard of Algeria use our findings to improve the thermal regulation, which is under development. The following step for our research project is to couple the solar thermal collector to two buried tanks connected in series or in parallel. The practical aspect of this step will be developed in future research projects.

\section{Conclusion}

The heating performance of Seasonal Solar Thermal Storage and EAHE Systems coupled to an experimental cell in Algerian climate was investigated. A thermal model was developed using TRNSYS, where its simulation results were validated by those obtained in the experiment. We present in the first step of this paper energy performance of combined geothermal system (UNT and EAHE) for heating needs. The results show that the water tank temperature varies between $18.3^{\circ} \mathrm{C}$ and $20^{\circ} \mathrm{C}$. To load this temperature, the UNT was coupled with a solar thermal collector. The combination of solar collectors, UNT, and EAHE systems provides an indoor air temperature gain of $7{ }^{\circ} \mathrm{C}$ compared to the case without a heat source. For the heating period of December, the energy provided by this combination is $435.4 \mathrm{KWh}$, which gives a coverage rate of $131 \%$. The excess energy could be used for other applications such as the domestic hot water. 
Based on the sensitivity analysis, several simulations are performed by varying the solar collector surface and the storage volume. The results confirm that smaller size solar collectors and storage volumes could be used to ensure the sustainability of the system for the Mediterranean context. For a solar collector surface of $2.6 \mathrm{~m}^{2}$ and a storage volume of 4 $\mathrm{m}^{3}$, the indoor air temperature varies between $18^{\circ} \mathrm{C}$ and $23^{\circ} \mathrm{C}$.

In addition, a financial and energy-saving analysis has been carried out based on the results of the simulations to show the interest of the proposed system compared to the conventional system, such as the boiler. Thanks to the geo-solar system, the energy consumption reduction for heating needs is around $232.8 \mathrm{kWh}$ (energy saving of 94\%). This reduction in consumption saves about 38 euros and reduces $\mathrm{CO} 2$ emission of 21.14 tons for the whole heating period.

\section{Declaration of Competing Interest}

The authors declare that they have no known competing financial interests or personal relationships that could have appeared to influence the work reported in this paper.

\section{References}

Algerian National Weather Office.

Amanowicz, L., Wojtkowiak, J., 2018. Validation of CFD model for simulation of multipipe earth-to-air heat exchangers (EAHEs) flow. Thermal Sci. Eng. Prog. 5, 44-49.

Banjac, M., 2015. Achieving sustainable work of the heat pump with the support of an underground water tank and solar collectors. Energy Build. 98, 19-26.

Benzaama, M.H., Menhoudj, S., Kontoleon, K.J., Mokhtari, A.M., Lekhal, M.C., 2018. Investigation of the thermal behavior of a combined geothermal systemfor cooling with regards to Algeria's climate. Sustainable Cities Soc. 43 (2018), 121-133.

Benzaama, M.H., Menhoudj, S., Maalouf, C., Mokhtari, A., Lachi, M., 2019. Experimental and numerical analysis of the energy performance of a water/ soil exchanger coupled to a cooling floor for North Africa. Geothermics 80, 8-19.

Bouraiou, A., Necaibia, A., Boutasseta, N., Mekhilef, S., Dabou, R., Ziane, A., Sahouane, N., Attoui, I., Mostefaoui, M., Touab, O., 2020. Status of renewable energy potential and utilization in Algeria. J. Cleaner Prod. 246, 11.

calculator CO2: http://calculateurco2.org/?lang=fr\#Accueil.

Chel, A., Janssens, A., De Paepe, M. Thermal performance of a nearly zero energy passive house integrated with the air-air heat exchanger and the earth-water heat exchanger. https://doi.org/10.1016/j.enbuild.2015.02.058.

Chiesa, G., Simonetti, M., Grosso, M., 2014. A 3-field earth-heat-exchange system for a school building in Imola, Italy: monitoring results. Renew. Energy 62, 563-570.

DTR C3-T, 2011. Thermal regulation of the building, Center for Integrated Study and Research of Buildings, Ministry of Housing and Urban Planning, Algeria.

Ghedamsi, R., Settou, N., Gouareh, A., Khamouli, A., Saifi, N., Recioui, B., Dokkar, B., 2016. Modeling and forecasting energy consumption for residential buildings in Algeria using bottom-up approach. Energy Build. 121, 309-317.

Hasan, H., Ismaeel, Yumruta, R., 2020. Investigation of a solar assisted heat pump wheat drying system with underground thermal energy storage tank. Sol. Energy 199, 538-551.

http://quopera.e-monsite.com/pages/estimation-en-ligne/cout-chauffage.html.

Huang, H., Xiao, Y., Lin, J., Zhou, T., Liu, Y., Zhao, Q., 2020. Thermal characteristics of a seasonal solar assisted heat pump heating system with an underground tank. Sustainable Cities Soc. 53, 101910.
Lekhal, M.C., Belarbi, R., Mokhtari, A.M., Benzaama, M.-H., Bennacer, R., 2019. Thermal performance of a residential house equipped with a combined system: a direct solar floor and an earth-air heat exchanger. Sustain. Cities Soc. 40, 534-545.

Lekhal, Mohammed Cherif, Benzaama, Mohammed-Hichem, Kindinis, Andrea, Mokhtari, Abderahmane-Mejedoub, Belarbi, Rafik, 2021. Effect of geo-climatic conditions and pipe material on heating performance of earth-air heat exchangers. Renewable Energy 163, 22-40.

Lizana, J., Ortiz, C., Soltero, V.M., Chacartegui, R., 2017. District heating systems based on low-carbon energy technologies in Mediterranean areas. Energy 120, 397-416.

Martin-Escudero, K., Salazar-Herran, E., Campos-Celador, A., Diarce-Belloso, G., GomezArriaran, I., 2019. Solar energy system for heating and domestic hot water supply by means of a heat pump coupled to a photovoltaic ventilated façade. Sol. Energy 183, 453-462.

Menhoudj, Sayeh, Mokhtari, Abderrahmane - Mejedoub, Benzaama, Mohamed-Hichem, Maalouf, Chadi, Lachi, Mohamed, Makhlouf, Mohammed, 2018. Study of the energy performance of an earth - air heat exchanger for refreshing buildings in Algeria. Energy Build. 158, 1602-1612.

Menhoudj, S., 2017. Intégration des systèmes à énergies renouvelables dans le Bâtiment: Evaluation des performances énergétiques. Thèse de doctorat, Université des sciences et de la technologie d'Oran.

Naranjo-Mendoza, C., Muyiwa, A., Andrew, J.O. Wright, Greenough, R., 2019. Experimental study of a domestic solar-assisted ground source heat pump with seasonal underground thermal energy storage through shallow boreholes. Appl. Therm. Eng. 162, 114218.

Nordell, B.o., Hellström, G., 2000. High temperature solar heated seasonal storage system for low temperature heating of buildings. Sol. Energy 69 (6), 511-523.

Ozgener, O., Ozgener, L., 2010. Exergetic assessment of EAHEs for building heating in Turkey: a greenhousecase study. Energy Policy 38 (9), 5141-5150.

Panno, D., Buscemi, A., Beccali, M., Chiaruzzi, C., Cipriani, G., Ciulla, G., Di Dio, V., Lo Brano, V., Bonomolo, M., 2019. A solar assisted seasonal borehole thermal energy system for a nonresidential building in the Mediterranean area. Sol. Energy 192, $120-132$.

Peel, M.C., Finlayson, B.L., McMahon, T.A., 2011. University of Melbourne.

Piderit, M.B., Vivanco, F., Van Moeseke, G., Attia, S., 2019. Net zero buildings-a framework for an integrated policy in Chile. Sustainability 11 (5), 1494.

Popiel, C.O., Wojtkowiak, J., Biernacka, B., 2001. Measurements of temperature distribution in ground. Exp. Therm. Fluid Sci. 25, 301-309. https://doi.org/ 10.1016/S0894-1777(01)00078-4.

Rosa, N., Soares, N., Costaa, J., Santos, P., Gervásio, H., 2020. Assessment of an earth-air heat exchanger (EAHE) system for residential buildings in warm-summer Mediterranean climate. Sustainable Energy Technol. Assess. 38, 100649.

Rosato, A., Ciervo, A., Ciampi, G., Scorpio, M., Sibilio, S., 2019. Impact of seasonal thermal energy storage design on the dynamic performance of a solar heating system serving a small-scale Italian district composed of residential and school buildings. J. Storage Mater. 25, 100889.

Sanz, Asier. Raquel Fuente and Antonio J. Martín, Solar hybrid PVT coupled heat pump systems towards cost-competitive NZEB. In: International Solar Energy Society EuroSun 2018 Conference Proceedings.

Stazi, F., Ulpiani, G., Pergolini, M., Di Perna, C., D’Orazio, M., 2020. The role of wall layers' properties on the thermal performance of ventilated facades: experimental investigation on narrow-cavity design. Energy Build. 209, 109622.

Thiers, S., Peuportier, B., 2008. Thermal and environmental assessment of a passive building equipped with an earth-to-air heat exchanger in France. Sol. Energy 82, 820-831.

Trillat-Berdal, V., Souyri, B., Fraisse, G., 2006. Experimental study of a ground-coupled heat pump combined with thermal solar collectors. Energy Build. 38 (12), $1477-1484$.

TRNSYS 16, 2005. TRaNsient SYstem Simulation program Volume 5 Mathematical Reference.

Ulpiani, G., Giuliani, D., Romagnoli, A., di Perna, C., 2017. Experimental monitoring of a sunspace applied to a NZEB mock-up: assessing and comparing the energy benefits of different configurations. Energy Build. 152, 194-215. 